\title{
CRITICAL DISCOURSE ANALYSIS - NEW POSSIBILITIES FOR SCIENTIFIC RESEARCH IN THE MENTAL HEALTH AREA
}

Leandro Barbosa de Pinho

Luciane Prado Kantorski

Antonio Miguel Bañon Hernández ${ }^{3}$

Pinho LB, Kantorski LP, Hernández AMB. Critical discourse analysis - new possibilities for scientific research in the mental health area. Rev Latino-am Enfermagem 2009 janeiro-fevereiro; 17(1):126-132.

The present study aims to get to know the philosophical, conceptual and methodological aspects of Critical Discourse Analysis, as a theoretical-methodological framework for research in the mental health area. Initially, the study presents a reflection on psychiatric discourse in history and at present, with the goal of introducing concepts and presuppositions that would guide the analysis of discursive processes. Discussions are presented about the historical milestones of Critical Discourse Analysis as an analytical framework in social sciences. Finally, the study presents its conceptual and methodological applications to research in the mental health area.

DESCRIPTORS: language arts; mental health; social sciences; linguistics

\section{ANÁLISIS CRÍTICO DEL DISCURSO: NUEVAS POSIBILIDADES PARA LA INVESTIGACIÓN CIENTÍFICA EN EL CAMPO DE LA SALUD MENTAL}

Este ensayo teórico buscó discutir los aspectos filosóficos, conceptuales y metodológicos del Análisis Crítico del Discurso como marco teórico-metodológico para realizar estudios en el área de la salud mental. En el inicio se reflexiona acerca del discurso psiquiátrico, en la historia y en la actualidad, para introducir conceptos e hipótesis que orientan el análisis de los procesos discursivos. Se discurre sobre los hitos históricos del Análisis Crítico del Discurso como marco analítico en el campo de las ciencias sociales. Se finaliza este ensayo presentando sus aplicaciones, conceptuales y metodológicas, en la investigación en el campo de la salud mental.

DESCRIPTORES: estudios del lenguaje; salud mental; ciencias sociales; lingüística

\section{ANÁLISE CRÍTICA DO DISCURSO - NOVAS POSSIBILIDADES PARA A INVESTIGAÇÃO CIENTÍFICA NO CAMPO DA SAÚDE MENTAL}

Este ensaio teórico procura discutir os aspectos filosóficos, conceituais e metodológicos da Análise Crítica do Discurso como referencial teórico-metodológico para estudos na área da saúde mental. No início há reflexão acerca do discurso psiquiátrico, na história e na atualidade, para introduzir conceitos e pressupostos que orientam a análise dos processos discursivos. Discorre-se sobre as demarcações históricas da Análise Crítica do Discurso como referencial analítico no campo das ciências sociais. Finaliza-se este ensaio apresentando suas aplicações conceituais e metodológicas à investigação no campo da saúde mental.

DESCRITORES: estudos de linguagem; saúde mental; ciências sociais; lingüística

${ }^{1}$ Assistant Professor at Faculdade de Enfermagem e Obstetrícia da Universidade Federal de Pelotas, Brasil, Doctoral student at Escola de Enfermagem de Ribeirão Preto, da Universidade de São Paulo, Centro Colaborador da OMS para o Desenvolvimento da Pesquisa em Enfermagem, Brazil, e-mail: Ibpinho@uol.com.br; ${ }^{2}$ Ph.D. in Nursing, Adjunct Professor at Faculdade de Enfermagem e Obstetrícia da Universidade Federal de Pelotas, Brazil, e-mail: kantorski@uol.com.br; ${ }^{3}$ Ph.D. in Philology, Full Professor at Universidade de Almería, Espanha, e-mail: amhernan@ual.es. 


\section{REFLECTIONS OF PSYCHIATRIC DISCOURSE IN HISTORY AND IN THE PRESENT}

In the health field, the development of knowledge and practices is a question that remains unclear. Discussions concerning health and disease often induce people into stating their point of view, be that in favor or against any particular view about the subject under discussion. This happens because health and disease are concepts produced within human relationships, and thus encourage thoughts and reflections and reveal the theoretical line that those people assume when they defend and state their understanding.

It is a fact that learning and producing any knowledge about health and disease cannot be done in isolation, even if considered from the perspective of the epistemological conflict provided by reflections. In some ways, it appears that this represents the ideological incursion of the subject into the social context. For this reason, the health-disease process assumes no less complex characteristics that, one way or another, affect one's way of being, conduct and human relationships. It is among these contradictions and conflicts that abstractions occur, people develop as humans and professionals, discourses are grounded and, in conclusion, the path is established to rethink - and transform - the world and reality.

In the academic scope, the health-disease process has always been included in various theoretical-epistemological conflicts and discussions. The reason for this is that creation - and, in this case, abstraction - calls for more complex constructions, and thus implies ruptures as well as resistances ${ }^{(1)}$. Examples of this occur in psychology, nursing and medicine. In psychology, paradigms can range from the most positivist - that value explanatory and causal findings, regardless of the study object - to the most existentialist ones - which are concerned with understanding the meanings and perceptions about a given issue for the subjects and their way of living. In nursing, the development of scientific studies, especially in stricto sensu ${ }^{(2)}$ graduate programs, using several paradigms and methodological devices from other knowledge areas, like those originated in social sciences, has permitted knowledge improvements in the profession, (re)inventing new health promotion practices that also cover the physical, emotional and social burdens resulting from the disease process.
It was in medicine, however, that the most substantial changes in the way of thinking about health and disease in humanity became more evident. In the case of mental health, specifically, it was when madness, through Phillipe Pinel and his followers, was elevated to the condition of mental disease, and the psychiatric hospital was considered the place for treatment and rehabilitation. As from this moment, the psychiatric discourse turns to the confluences of a rational knowledge, eager for explanations of the findings about the subjects and their symptom manifestations, as well as for the methodological organization of these findings, so as to begin the classification of the several "genres" of the psychiatric disease $^{(3-5)}$

At the same time as the reality of medicalpsychiatric research production rises as a "new scientific knowledge", it consolidates a medicaldominant discourse that defends and disseminates the need for these practices. Taking advantage of the medical hegemony of the $19^{\text {th }}$ century, with the birth of Cartesian scientific rationalism ${ }^{(6)}$, psychiatry finds the subterfuge to overlook the empirical contemplations and incorporate evidence-based knowledge and practices, such as classification efforts, the implementation of therapies, hospital discharges and new admissions, all of which are performed in modern psychiatric hospitals ${ }^{(7)}$.

As observed, the discourse about mental health as the object of intervention and medical attention is dominant in the psychiatric care context, until today. However, the criticism disseminated throughout the $20^{\text {th }}$ century, especially after World War II, played a decisive role in the criticism against the medical-psychiatric discourse, since it recommended a practice that was observatory, pedagogical, and merely causal and centered in the psychiatric hospital as a place for "treatment" and "rehabilitation".

It is in this context of changes that one considers broadening the object of knowledge in psychiatry, which consequently resulted in the development of new discourses in the area. It is no longer a goal to focus on the care delivered in psychiatric hospitals because it apparently is not the best therapeutic environment. The aim is to focus on the production of life within the community, teaching the idea of care in the territory the subject inhabits and including the family in this treatment. In a more subjective dimension, one of the goals is to work with the subject, who is suffering and needs care, attention, sympathy, welcoming and understanding. 
Some factors can be outlined which would develop this new discourse, of a reformist nature: increased world health consciousness, encouraging patients, families and professionals to fight for better life conditions and treatment, the gradual acceptance that care can be provided in the community and the phenomenon of deinstitutionalization, which was taking place in several countries ${ }^{(8)}$. In this sense, different movements are consolidated with the aim of fighting against the increasingly chronic patients and the social disabilities caused by hospitalization. Among them are the English therapeutic communities, the French institutional psychotherapy, the American community psychiatry, and the French sector psychiatry. The two latter movements have influenced the Italian psychiatric reform, later adopted as the theoretical model to subsidize other reforms, including the one taking place in $\mathrm{Brazil}^{(9)}$.

In the case of Brazil, the psychiatric reform has made it possible to develop new discourses in the health area, revealing facets that were once obscure due to the excluding nature of traditional psychiatry. Today, there are talks about Psychosocial Care Centers replacing asylums. Madness is not referred to as an object of apprehension, but as an experience of suffering, a participant-being, a complexity of manifestations. There are talks about treatment and care: treatment as a reflection and care as the focus; treatment as a project and care as the condition.

As observed, a discourse does not exclusively aim at expressing a certain point of view of a subject or specific social group. Discourse is immersed in human life as the production of society and as an act of language activity. It instigates the development of socio-historical regularities and irregularities. Discourse questions the formation of individuals; it produces knowledge, just like it produces and reproduces practices. It is this reality that critical discourse analysis seeks to understand and which this essay looks at.

\section{DISCOURSE ANALYSIS - HISTORICAL MILESTONES}

Discourse analysis is a theoretical and methodological subject that seeks, within the area of human sciences, to unveil the linguistic singularities of discourse as a social production. It represents the possibility of looking at everyday events as semiotic manifestations, i.e. materialized in the language activities and containing meanings, thus determining, in some way, how, when, and why some phenomena in life assume regularities or discontinuities ${ }^{(10-11)}$.

Historically, two philosophical-theoretical guidelines have already been concerned with the aspect of positioning and outlining the object of study: realistic subjectivism and abstract objectivism. The first tendency, of which Wilhelm Humboldt is one of the greatest precursors, is interested in the "act of speech", i.e. individual creation as the foundation of language (in the broad sense of any language with no exception). The second tendency, of which origins are firmed on Cartesian rationalism of the $17^{\text {th }}$ and $18^{\text {th }}$ century, considers language as an activity centered on a linguistic system with phonetic, grammatical and lexical structures. While in the first guideline language can be characterized as a flow of speech acts, abstract objectivism considers language an immutable object, which dominates this flow, and is unique, irreducible and individual ${ }^{(12)}$.

Linguistics, however, as it is known today, originates from the studies by Ferdinand de Saussure and his analysis of anagrams, to show how there is a latent text under a poetic text acting in the reader's mind. Since language originates internally, Saussure referred to it as a system, because its elements only acquire value when they relate with the whole context they are part of. The Saussurian system, a posteriori, is refereed to as structure by its successors, giving a structural position to the science that begins to unveil language and its internal/external relationships with the world $^{(13)}$.

The structuralist line of modern linguistics only reached its height the 1960's, with the studies by Lévi-Strauss and Michel Pêcheux. Lévi-Strauss sought to articulate human science knowledge (anthropology, sociology, philosophy) to show that the Saussurian perspective of language as a closed system causes a conceptual change, since there are other parallel systems (mythical, literary) with internal and external relationships with language itself. On the other hand, Pêcheux, based on the studies by Karl Marx and Louis Althusser, completely rejected the idea of language as a communication tool nothing more than an ideology, which confuses the political practice, and makes this articulation obscure. To show these linguistic particularities of a given event and the produced meaning effects, Pêcheux designed the first 
experimental discourse analysis device, known as the automatic discourse analysis ${ }^{(11,14)}$.

More specifically in the 1960's and 1970's, a new theoretical-philosophical movement referred to as linguistic turn caused a change in philosophy paradigms and in various human and social sciences, encouraging a stronger emphasis in the interior/ exterior aspects of language, in the projects of the subjects studying it, as well as in the formation of the phenomena it usually studies ${ }^{(15-16)}$.

The linguistic turn firmed itself as a theoreticalphilosophical movement at the interface of three stages of language philosophy development. In the first, stemming from the Cartesian thought that founded consciousness philosophy, language is a vehicle to express ideas and nothing else. In the second, with a neo-positivist direction, language becomes a representation of the reality, changing the study of "ideas" to the study of objective events, i.e., the discourses, since they are the ones that correspond to the objects of the world. As for the third, it places language in the center of philosophical research, when European linguists, who had migrated to the United States due to Nazi persecutions, inaugurated the epistemological rupture with the Cartesian tradition, referring to language not merely as the expression of ideas. In this sense, language "does things" and is the "creator" of realities, and its results can be made explicit and analyzed in the light of the scientific knowledge produced by human/social sciences ${ }^{(17)}$.

The main influence on the critical perspective of discourse analysis was "critical linguistics", a theoretical line of language studies in articulation with the critical social sciences, especially the ones based on the philosophical presupposition of the Frankfurt School, which aimed to identify, understand and correlate the whole range of possibilities of linguistic formations that form the structure of power in society. However, the critical perspective of discourse analysis also stemmed from the connection of a dialectical theory with an analysis method that permitted attributing meanings to the social practices, with discourse as the center of these manifestations ${ }^{(18)}$.

It is the possibility of articulating several types of knowledge produced by social sciences that gives critical discourse analysis a cross-disciplinary character. Different types of focus exist in critical discourse analysis. Some of the most influent linguists are Sigfried Jäger, Ron Scollon, Teun Van Dijk and Norman Fairclough. The first follows a Foucaultian* line of work, and defines discourse as a "device" of interrelated discursive and non-discursive practices that materialize in the world. Scollon, on the other hand, follows micro-sociology to define the discursive dimension, and considers discourse the production/ reproduction of everyday facts and action in human interactions. Van Dijk presents a line of socio-cognitive psychology in which discourse becomes a communicative event that includes texts, interaction, gestures, expressions, and images that produce the meaningful dimension of life. Finally, Fairclough presents a Marxist direction for discourse, in which it is seen as a social production that represents social conflicts, particularly centered on the elements of domination, inequality and resistances ${ }^{(19)}$.

Within the health context, the workers' discourse says a lot about what they think, understand and act in terms of the different aspects of the disease process. This means that their discourses appear to modify the environment, but also seem to be modified by it. In some ways, social context and discourses seem to be "flexible" to everyday changes and to the knowledge that individuals produce about themselves within their relationship with this material world. In this sense, the critical discourse analysis emerges as a theoretical-methodological possibility to explain the discursive phenomena in the different health knowledge areas, taking into consideration its complexity and articulations, since discourse is the creator of practices, just like practices can comprise different discourses.

Below, other conceptual questions are presented to outline the line of critical discourse analysis chosen for the reflections contained in this study.

\section{CRITICAL DISCOURSE ANALYSIS - CONCEPTUAL AND METHODOLOGICAL APPROACHES IN MENTAL HEALTH}

Every discourse makes sense and has meaning. In some ways, in everyday language, it is quite common to find references to discourse as a

*In the mental health context, some studies in this same line supported knowledge about the social production of psychiatric discourse and its effects on the development of the modes of intervention for the madness phenomenon. The most classic study about this theme (4) recreates the history of knowledge and practice about madness, considering the development of psychiatric discourse and the organization of society in terms of working with the disease. Special highlight was given to knowledge production, power relationships and the historical constitution of the medical intervention practices that reduced the madness phenomena to mental disease. 
type of communicative activity. Although it is applied to one of the forms of language use, it can be disseminated in the social environment in a more "informal" fashion, designating specific knowledge to specific areas, such as "neoliberal discourse", "medical discourse" and "television media discourse"(20).

As observed, people live with discourse everyday without noticing its complexity. As a dimension of material life and contemporary language, discourse represents part of what one is and does, in the same way as it is represented by what one is and does. In this sense, discourses have different meanings in human lives and in society; and are needed in order to promote specific types of knowledge and reflections, to encourage conflicts, disseminate ideologies and persuade people or social groups.

One example of how discourse meanings can serve different purposes in society is the constitution of $19^{\text {th }}$-century psychiatric discourse. In that period, psychiatric discourse was not characterized by privileged objects, but rather by how these objects were formed by medicine. In order to speak about such objects, it was necessary to raise discourse to the level of social practice, because discourse can only "develop" objects when they can be addressed, analyzed, classified and explained. That was how a discourse unit about madness was created. Mental medicine was able to define it as a pathological dimension; not as a type of knowledge, but as a type of practice, i.e. madness as a component of the mechanisms of repression, jurisprudence, theological understanding, the object of nosological diagnosis and pathological descriptions. Hence, discourse is not a representation of elements but, rather, it consists of practices that systematically develop the referred objects $^{(21)}$.

Discourse can be understood as a "linguistic activity in action", as a moment of social practices, which can be analyzed in terms of its (internal/ external) structure and action (social repercussion). Social practice is also a "production practice", i.e. an arena where human life and language ability are produced/reproduced as they occur in economy, politics, culture and everyday events and - in this case - in the health field ${ }^{(18,22)}$.

In this sense, discourse is not only, but also a linguistic and extralinguistic representation of men. It is linguistic because it materialized in human speech and writing. It is extralinguistic because it is immersed in everyday life activities, in the social-historical materiality of the subject, in the constitution of social existence, in the "events" of the world. It comprises a 'becoming', a relation, a sense, a meaning, a reaction with one or many expressions. But, more than this, it is a social action, an action in relation. Discourse as the result of social processes, as socialization, as social construction, but also as the process of making the linguistic act of men in the world something unique.

The theoretical-methodological device of critical discourse analysis adopted here is the threedimensional model of discourse ${ }^{(22)}$. In this model, discourse is analyzed based on three essential dimensions: the analysis of discourse as a text, discourse as a discursive practice, and discourse as a social practice. All these dimensions are dialectically related, and are part of the analytic dynamics of the discursive material as a whole. The image below synthesizes the three-dimensional configuration of discourse for the author.

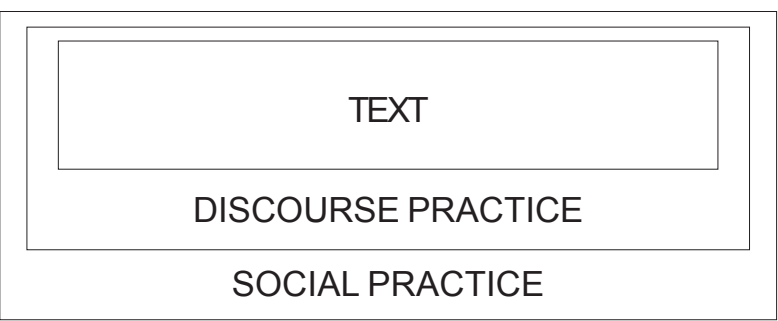

Figure 1 - Three-dimensional concept of discourse ${ }^{* *(22)}$

The analysis of discourse as a text permits studying the internal mechanisms of its production, such as vocabulary, grammar, semantics, cohesion and structure. The study about grammar and vocabulary covers individual words or articulated expressions, as well as some language properties that become clear in discourse (neologisms, lexicalizations, metaphors, nominalizations). In terms of cohesion, it concerns the elements that link phrases, including individual sentences and inter-sequential cohesion. Semantic analysis studies elements regarding inference, implications, meanings extracted from the internal (and external) discourse.

The analysis of discursive practices permits studying the mechanisms that promote the articulation of different discourses, because one discourse is always interconnected to its "internal" and "external" aspects. Therefore, the discursive practice permits the analysis of discourse as a text and as a social practice. In this category, intertextuality and 
interdiscursivity are studied. They are responsible for connecting one text to the other, and permit thinking about the dialogical strength of discourse as sociohistorical material.

Regarding mental health research, through intertextuality and interdiscursivity, it is possible to extract the contents about a certain subject of interest, incorporating different or similar discourses, combining specific elements and showing how, why and when these elements are compatible or incompatible in the studied everyday environment.

In the case of discourse analysis as a social practice, the study looks at the repercussions of this discourse on the socio-historical materiality of the subjects, what characteristics produce continuities and discontinuities and how certain discursive events are included in human life, immerging in social activities and social interaction. Within this context, a sociological analysis of the discursive events is performed, focused on the ideological and hegemonic movements originated from the social processes and that reflect on social practices as well as on the discursive materiality.

In the case of discursive analysis in mental health, one can think about how, when and why the discourses produced in the area influence the constitution of society and the way it relates with the madness phenomena. It is also concluded that the battles and displacements certain discourses provoke in social relationships, so as to evidence the fragility, strength, weaknesses and contradictions in the everyday lives of the subjects who experience or think that madness is a dimension of human life.

Finally, the characteristics outlined by critical discourse analysis, although not comprehensive about its knowledge, appear to reveal the multiple possibilities of contact between different scientific knowledge areas. In this case, the three-dimensional model of discourse ${ }^{(22)}$ is simply one of the several critical lines of discourse analysis. However, it is observed that it is fertile ground for new scientific discoveries about the life-related phenomenon, creating knowledge, practices and new relationships in the health area, complex and in constant transformation.

\section{FINAL CONSIDERATIONS}

The present theoretical study revealed only a few of the many aspects that make it possible to articulate the different types of knowledge produced in specific areas, such as linguistics, in the health area. Furthermore, it outlined some approximations and new theoretical-methodological approaches to produce knowledge about certain aspects concerning the process of living and falling ill, and that materialize in the discourses, considering them as a fundamental activity of language and as a mechanism to produce meanings in everyday life.

In the case of mental health, critical discourse analysis is structured as a subject aimed at studying the semiotic phenomenon of which madness is the study object and the dimension of the health-disease process. More specifically, critical discourse analysis can help to unveil specificities not only in linguistic but also in sociological terms, such as personalities, conflicts, positions, resistances, coping and assimilations. On the other hand, it is this comprehensive analysis that will determine how the ideological and hegemonic movement moves dialectically in the field of psychiatry, producing new (and old) discourses filled with contradictions, possibilities and limitations.

\section{REFERENCES}

1. Brant LC, Minayo-Gomez C. A transformação do sofrimento em adoecimento: do nascimento da clínica à psicodinâmica do trabalho. Ciência e Saúde Coletiva 2004 janeiro; 9(1):213-23. 2. Erdmann AL, Silva IA, Rodrigues RAP, Fernandes JD, Vianna LAC, Marques MJL et al. Teses produzidas nos programas de pós-graduação em enfermagem de 1983 a 2001. Rev Esc Enferm USP 2005 dezembro; 39(especial):497-505.

3. Griffiths L. Categorizing to exclude: the discursive construction of cases in community mental health teams. Sociol Health \& Illness 2001 September; 23(1):678-700.
4. Foucault M. História da Loucura. $8^{a}$ ed. São Paulo (SP): Perspectiva; 2003.

5. Pessotti I. A loucura e as épocas. Rio de Janeiro (RJ): 34; 1994.

6. Foucault M. O nascimento da clínica. 6a ed. Rio de Janeiro (RJ): Forense Universitária; 2004.

7. Vietta EP, Kodato S, Furlan R. Reflexões sobre a transição paradigmática em saúde mental. Rev Latino-am Enfermagem 2001; 9(2):97-103.

8. Saraceno B, Frattura L, Bertolote JM. Evaluation of psychiatric services: hard and soft indicators. In: World Health Organization, organizador. Innovative approaches in service 
evaluation. Geneva (Switzerland): World Health Organization; 1993. p. 1-48.

9. Birman J, Costa JF. Organização de instituições para uma psiquiatria comunitária. In: Amarante $\mathrm{P}$, organizador. Psiquiatria social e reforma psiquiátrica. Rio de Janeiro (RJ): FIOCRUZ; 1994. p. 41-72.

10. Maingueneau D. Novas tendências em análise do discurso. 3a ed. Campinas (SP): Pontes; 1997.

11. Orlandi EP. Análise de discurso. In: Orlandi EP, LagazziRodrigues S, organizadoras. Discurso e textualidade. Campinas (SP): Pontes Editores; 2006. p. 11-32.

12. Bakhtin M. Marxismo e filosofia da linguagem. $12^{\mathrm{a}}$ ed. São Paulo (SP): Hucitec; 2006.

13. Capelle MC, Melo MCOL, Gonçalves CA. Análise de conteúdo e análise de discurso nas ciências sociais. Rev Admin UFLA janeiro 2003; 5(1):69-85.

14. Pêcheux M. Análise automática do discurso. In: Gadet $F$, Hak T, organizadores. Por uma análise automática do discurso: uma introdução à obra de Michel Pêcheux. Campinas (SP): Unicamp; 1990. p. 61-161.

15. Spink MJP, Frezza RM. Práticas discursivas e produção de sentidos: a perspectiva da Psicologia Social. In: Spink
MJ, organizadora. Práticas discursivas e produção de sentidos no cotidiano: aproximações teóricas e metodológicas. São Paulo (SP): Cortez; 2000. p. 17-40.

16. Iñiguez L. Os fundamentos da análise de discurso. In: Iñiguez $L$, organizador. Manual de análise do discurso em ciências sociais. Petrópolis (RJ): Vozes; 2004. p. 50-104. 17. Gracia TI. O "giro lingüístico". In: Iñiguez L, organizador. Manual de análise do discurso em ciências sociais. Petrópolis (RJ): Vozes; 2004. p. 19-49.

18. Fairclough N. Analysing discourse - textual analysis for social research. 4a ed. Great Britain (UK): MPG Books; 2006. 19. Meyer M. Between theory, method, and politics. Positioning of the approaches to CDA. In: Wodak R, Meyer M, organizadores. Methods of critical discourse analysis. $5^{a}$ ed. London (UK): SAGE Publications; 2006. p. 14-31.

20. Van Dijk TA. El estudio del discurso. In: Van Dijk TA, organizador. El discurso como estructura y proceso. $3^{a}$ ed. Barcelona (Spain): Gedisa; 2006. p. 21-66.

21. Foucault M. Arqueologia do saber. $7^{a}$ ed. Rio de Janeiro (RJ): Forense Universitária; 2005.

22. Fairclough N. Discourse and social change. $11^{\mathrm{a}}$ ed. Cambridge (UK): Polity Press; 2006. 